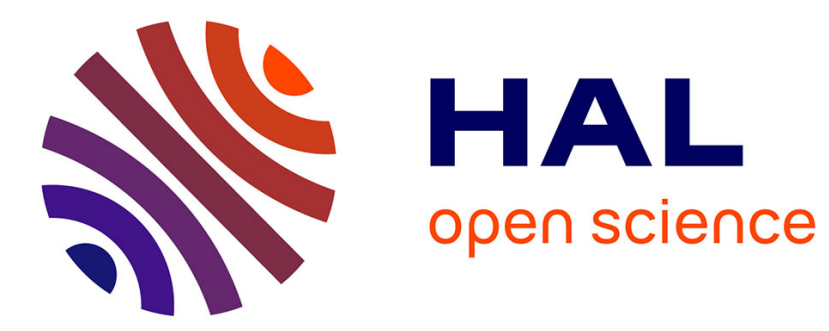

\title{
Horst Inversion Within a Décollement Zone During Extension Upper Rhine Graben, France
}

\author{
Joachim Place, M Diraison, Yves Géraud, Hemin A Koyi
}

\section{To cite this version:}

Joachim Place, M Diraison, Yves Géraud, Hemin A Koyi. Horst Inversion Within a Décollement Zone During Extension Upper Rhine Graben, France. Atlas of Structural Geological Interpretation from Seismic Images, 2018. hal-02959693

\section{HAL Id: hal-02959693 https://hal.science/hal-02959693}

Submitted on 7 Oct 2020

HAL is a multi-disciplinary open access archive for the deposit and dissemination of scientific research documents, whether they are published or not. The documents may come from teaching and research institutions in France or abroad, or from public or private research centers.
L'archive ouverte pluridisciplinaire HAL, est destinée au dépôt et à la diffusion de documents scientifiques de niveau recherche, publiés ou non, émanant des établissements d'enseignement et de recherche français ou étrangers, des laboratoires publics ou privés. 


\title{
Horst Inversion Within a Décollement Zone During Extension Upper Rhine Graben, France
} Joachim Place*1, M. Diraison ${ }^{2}$, Y. Géraud ${ }^{3}$, and Hemin A. Koyi ${ }^{4}$

\author{
${ }^{1}$ Formerly at Department of Earth Sciences, Uppsala University, Sweden \\ 2 Institut de Physique du Globe de Strasbourg (IPGS), Université de Strasbourg/EOST, Strasbourg, France \\ 3 Université de Lorraine, Vandoeuvre-lès-Nancy, France \\ ${ }^{4}$ Department of Earth Sciences, Uppsala University, Sweden \\ * joachim.geo@gmail.com
}

The Merkwiller-Pechelbronn oil field of the Upper Rhine Graben has been a target for hydrocarbon exploration for over a century. The occurrence of the hydrocarbons is thought to be related to the noticeably high geothermal gradient of the area. Its magnitude peaks at about $100{ }^{\circ} \mathrm{C} \cdot \mathrm{km}^{-1}$ a few kilometres east of the oil field, in the vicinity of the Soultz-sousForêts horst, which has been the target of geothermal exploration in recent decades (Figure 7.1). Seismic investigations in the $40 \mathrm{~km}$ wide Upper Rhine Graben reveal significant details. We have chosen a $5 \mathrm{~km}$ time-migrated section of the PHN84J profile that focuses on the eastern flank of the Soultz-sous-Forets horst to illustrate the complexity of basementsedimentary cover deformation patterns involving décollements (Figure 7.2). This is a slightly revised version of the original interpretation of Place et al. (2010), where the deformation in the décollement level was more emphasized than in the present interpretation.

The section shows a couple of major normal faults bounding a graben within the upper part of the sedimentary cover, rooted in décollements of Triassic anhydrite or clay series (top of Buntsandstein to Middle Muschelkalk, and Keuper). These faults are interpreted to have been active during the Oligocene when the Upper Rhine Graben opened (Roussé, 2006). The seismic profile also reveals the presence of a deeply-located fault-bounded block labelled (1) within the décollement zone. This block, which we call 'inverted horst', has formed in two main stages:

Firstly, extension in the basement (along at least one basement fault), decoupled from the cover by décollement level(s), resulted in the formation of a large-scale monocline

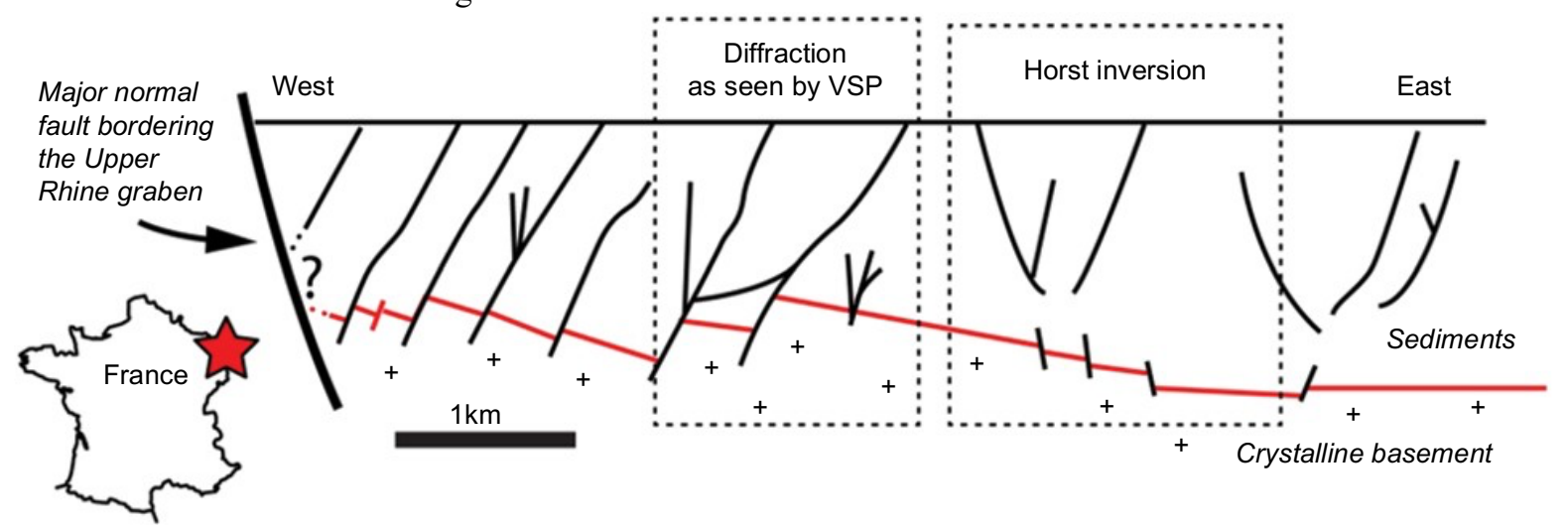

Figure 7.1 Regional geologic section showing the study areas for Chapters 7 and 8. 
(a)

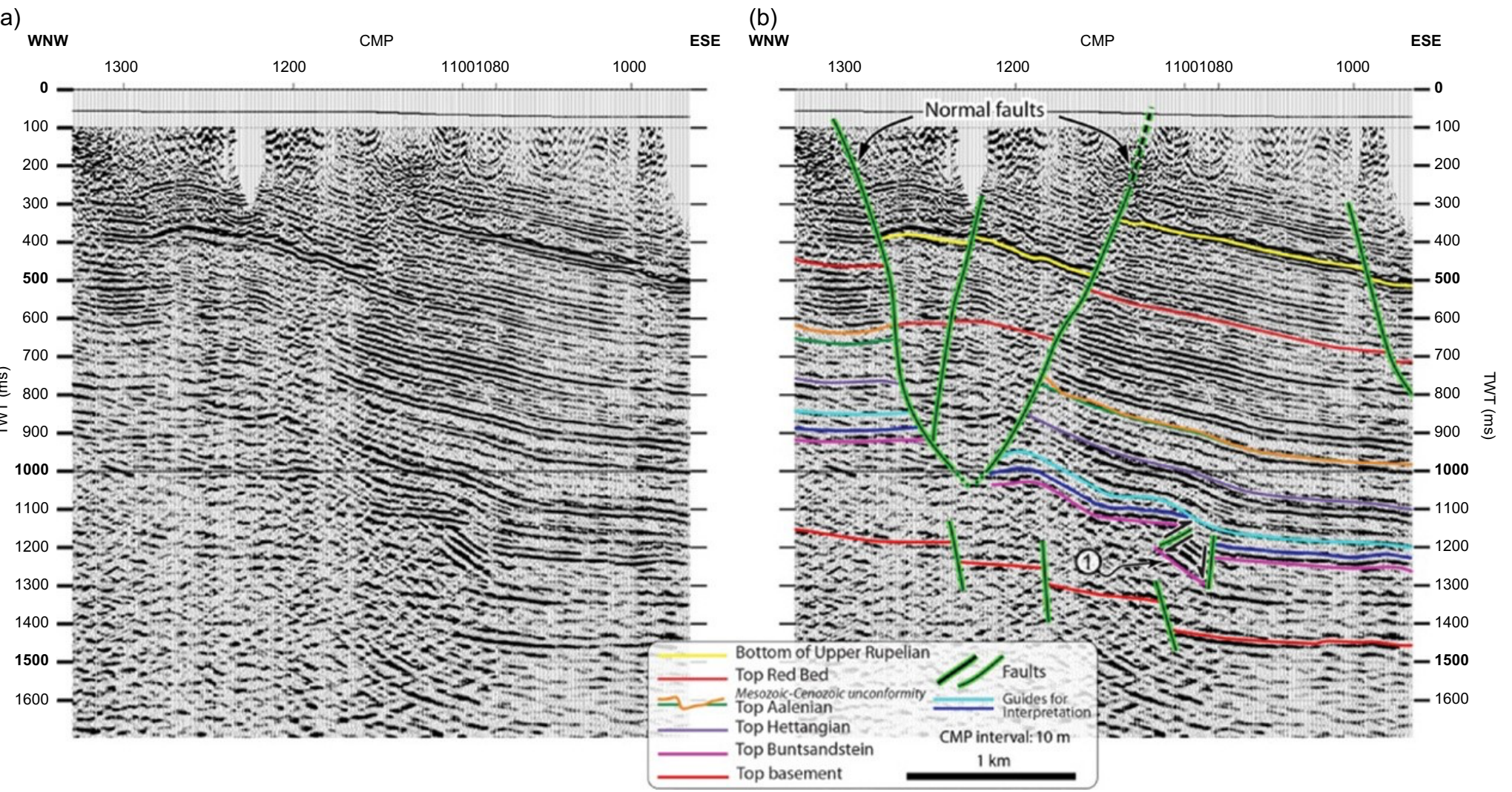

Figure 7.2 (a) Uninterpreted and (b) interpreted reflection seismic section showing the normal faults and the inverted horst block. Place et al. 2010. Reproduced with permission of Elsevier. Copyright (C 2010, published by Elsevier Masson SAS. All rights reserved.

and a graben in the cover units (Figure 7.3a). The upper reflectors within the graben exhibit some thickening and bending towards the western fault (synthetic to basement faults), denoting a syn-tectonic deposition, and not any drag that sometimes associate with faults (Mukherjee, 2014 and Koyi et al., 1993). The extensional regime also formed a detached deeply-located horst near the hangingwall hinge of the monocline (as obtained by Withjack and Callaway (2000) using analogue modelling) (Figures 7.2 and 7.3a).

Secondly, continued extension resulted in the eastern shoulder of the graben (about CMP 1120 and lower) to decouple from the basement and glide eastward on the ductile material. This ductile material, most likely made of Triassic clay and salt, also facilitated the popping down of the horst (1) alongside its inversion and clockwise rotation (Figure 7.3b). Concomitant bending of the reflectors above this inverted horst (1) attenuates upwards away from it (Figure 7.2). A slight clockwise rotation of the graben is also caused by the gliding of its eastern shoulder.

Interpretation of other seismic profiles indicates that the graben strikes around $\mathrm{N} 170^{\circ} \mathrm{E}$, which makes it prone to undergo Chattian compression (the maximum horizontal stress being NE-SW), and possible transpression when exposed to the Miocene to present Alpine push (oriented NW-SE) (Schumacher, 2002; Bourgeois et al., 2005). These two tectonic events might have 
bent the upper layers in the graben (about 200-400 ms and CMP 1260) as well as causing out-of-plane flow of ductile material within the décollement zones.

\section{References}

Bourgeois O., Ford M., Diraison M. et al. 2007. Separation of rifting and lithospheric folding signatures in the NWAlpine foreland. International Journal of Earth Sciences, 96, 1003-1031.

Koyi, H. A., Jenyon, M.K. and Petersen K. 1993. The effect of basement faulting on diapirism. Journal of Petroleum Geology, 16(3), 285-312.

Mukherjee, S. 2014. Review of flanking structures in meso- and micro-scales. Geological Magazine, 151, 957-974.

Place J., Diraison M., Naville C. et al. 2010. Decoupling of deformation in the Upper Rhine Graben sediments. Seismic reflection and diffraction on 3-component Vertical Seismic Profiling (Soultz-sous-Forêts area).

Comptes Rendus Geoscience, 342, 575-586.

(a)

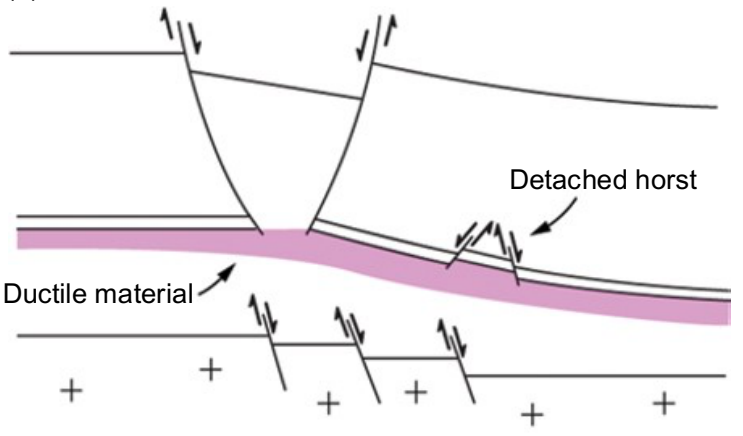

(b)

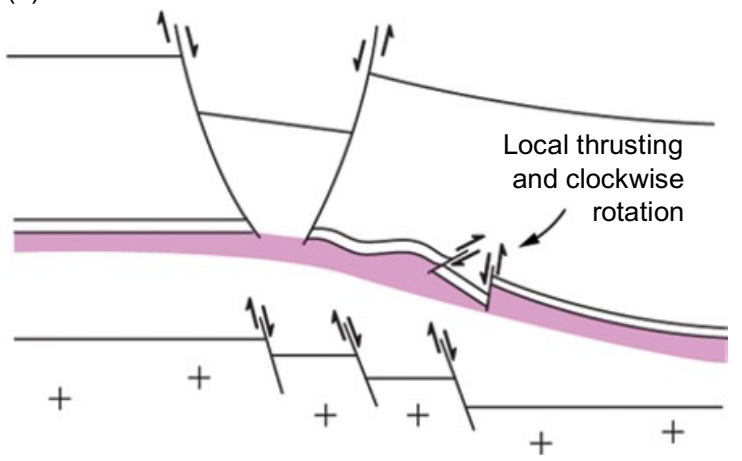

Figure 7.3 Schematic cross-section showing the two stage process for formation of the inverted horst block. (a) Stage 1 and (b) Stage 2.

Roussé, S. 2006. Architecture et dynamique des séries marines et continentales de l'Oligocène Moyen et Supérieur du Sud du Fossé Rhénan: évolution des milieux de dépôt en contexte de rift en marge de l'avant pays alpin. PhD Thesis, University of Strasbourg, France.

Schumacher, M.E. 2002. Upper Rhine Graben: Role of preexisting structures during rift evolution. Tectonics, 21(1), 6-1-6-17. doi: $10.1029 / 2001$ TC900022. 
Withjack, M.O. and Callaway, S., 2000. Active normal faulting beneath a salt layer: an experimental study of deformation patterns in the cover sequence. AAPG Bulletin, 84, 627-651. 
